\title{
Contributions to the smut fungi of Africa. 4. Taxonomic re-examination and emended description of Bauerago capensis
}

\section{Teodor T. Denchev* \& Cvetomir M. Denchev}

Institute of Biodiversity and Ecosystem Research, Bulgarian Academy of Sciences, 2 Gagarin St., 1113 Sofia, Bulgaria

Received 22 December 2017 / Accepted 16 January 2018 / Published 18 January 2018

Denchev, T.T. \& Denchev, C.M. 2018. Contributions to the smut fungi of Africa. 4. Taxonomic re-examination and emended description of Bauerago capensis. - Mycobiota 8: 1-7. doi: 10.12664/ mycobiota.2018.08.01

Abstract. A type specimen of Bauerago capensis, a smut fungus endemic to the Cape Floristic Region, is re-examined and designated as a lectotype. An emended description of that species and for the first time, illustrations of the spores in SEM are presented.

Key words: Africa, Bauerago, Cape Floristic Region, Juncaceae, Juncus capensis, Microbotryaceae, smut fungi, South Africa, taxonomy

\section{Introduction}

Bauerago is a small genus in the Microbotryales comprising nine species on host plants belonging to three, monocotyledonous families, namely, Commelinaceae (Commelina and Tinantia), Cyperaceae (Cyperus), and Juncaceae (Juncus and Luzula). Their sori destroy ovules of infected plants, filling the capsules (achenes, in the cases of host plants in Cyperus) with spores. The sori lack peridia and columellae, and there are no sterile cells between the spores (Vánky 2013).

Two species of Bauerago, B. abstrusa (Malençon) Vánky and B. capensis, are known to infect species of Juncus (Reess 1875a; Malençon 1929; Zundel 1938; Vánky \& McKenzie 2002; Vánky 2011; Vánky et al. 2011). Bauerago abstrusa is reported from Europe and New Zealand on rushes in Juncus subg. Agathryon Raf., members of two sections, Juncus sect. Steirochloa Griseb. (J. gerardii Loisel.) and Juncus sect. Juncotypus Dumort. (J. balticus Willd. and J. gregiflorus L.A.S. Johnson), while B. capensis is known to infect only two

\footnotetext{
*Corresponding author: e-mail: ttdenchev@gmail.com
} 
rushes in Juncus subg. Agathryon Raf., members of Juncus sect. Graminifolii Engelm. (J. lomatophyllus Spreng. and J. capensis Thunb.).

Ustilago capensis was described from two specimens of rushes that were examined by F. Buchenau for preparation of a monographic treatment of the Juncaceae of the Cape of Good Hope region (see Buchenau 1875: 486, 1906: 32). Buchenau noticed that the plants were infected by a smut fungus and sent them to M. Reess who described Ustilago capensis (Reess 1875a, in the same year, re-published as Reess 1875b, c). The description was accompanied by an illustration of the spore ornamentation (Pl. XI, 3-4). A type specimen of Ustilago capensis was compared with the type of $U$. vuyckii by Oudemans \& Beijerinck (1895: 56) who found them to be different. The type specimens of Ustilago capensis have not been examined anymore. In the Zundel's monograph of the Ustilaginales of South Africa (1938), a compilation of the description of U. capensis, obtained from Saccardo's Sylloge Fungorum (Saccardo 1888: 478), is given, without information about the herbarium where the authentic specimens of $U$. capensis were kept. Vánky (2011: 84) noted that "no specimen of this species could be located".

A type specimen of Ustilago capensis was found by us among Buchenau's specimens of Juncus capensis, kept at the herbarium of the Natural History Museum Vienna (W). This smut fungus was re-examined and its emended description is presented herein.

\section{Material and methods}

A dried specimen from the herbarium of the Natural History Museum Vienna (W) was examined with a light microscope (LM) and scanning electron microscope (SEM). For LM observations and measurements, spores were mounted in lactoglycerol solution ( $\mathrm{w}$ : la $: \mathrm{gl}=1: 1: 2$ ) on glass slides, gently heated to boiling point to rehydrate the spores, and then cooled. The measurements of spores are given in the form: min-max (extreme values) (mean \pm 1 standard deviation). For SEM, spores were attached to specimen holders by double-sided adhesive tape and coated with platinum in an ion sputter. The surface structure of spores was observed and photographed at $10 \mathrm{kV}$ accelerating voltage using a JEOL JSM 6610-LV scanning electron microscope. The description given below is based entirely on the specimen examined.

\section{Taxonomy}

Bauerago capensis (Reess) Vánky, Mycotaxon 70: 44, 1999, emend. T. Denchev \& Denchev Figs 2-9

$\equiv$ Ustilago capensis Reess, Sitzungsberichte der Physikalisch-Medizinischen Sozietät zu Erlangen 7: 70, 1875.

三 Cintractia capensis (Reess) Cif., Annales Mycologici 29(1-2): 72, 1931.

Sori destroying the ovules, filling the capsules with a semi-agglutinated, light to moderate orange-yellow (saffron, based on the Rayner's colour chart; Rayner 1970) spore mass. Infection systemic. Spores globose, subglobose, broadly ellipsoidal or ovoid, (10.5-)12$17.5(-18.5) \times(8.5-) 10-15.5(-16.5)(14.5 \pm 1.5 \times 13.1 \pm 1.3) \mu \mathrm{m}(\mathrm{n}=100)$, light yellowish 


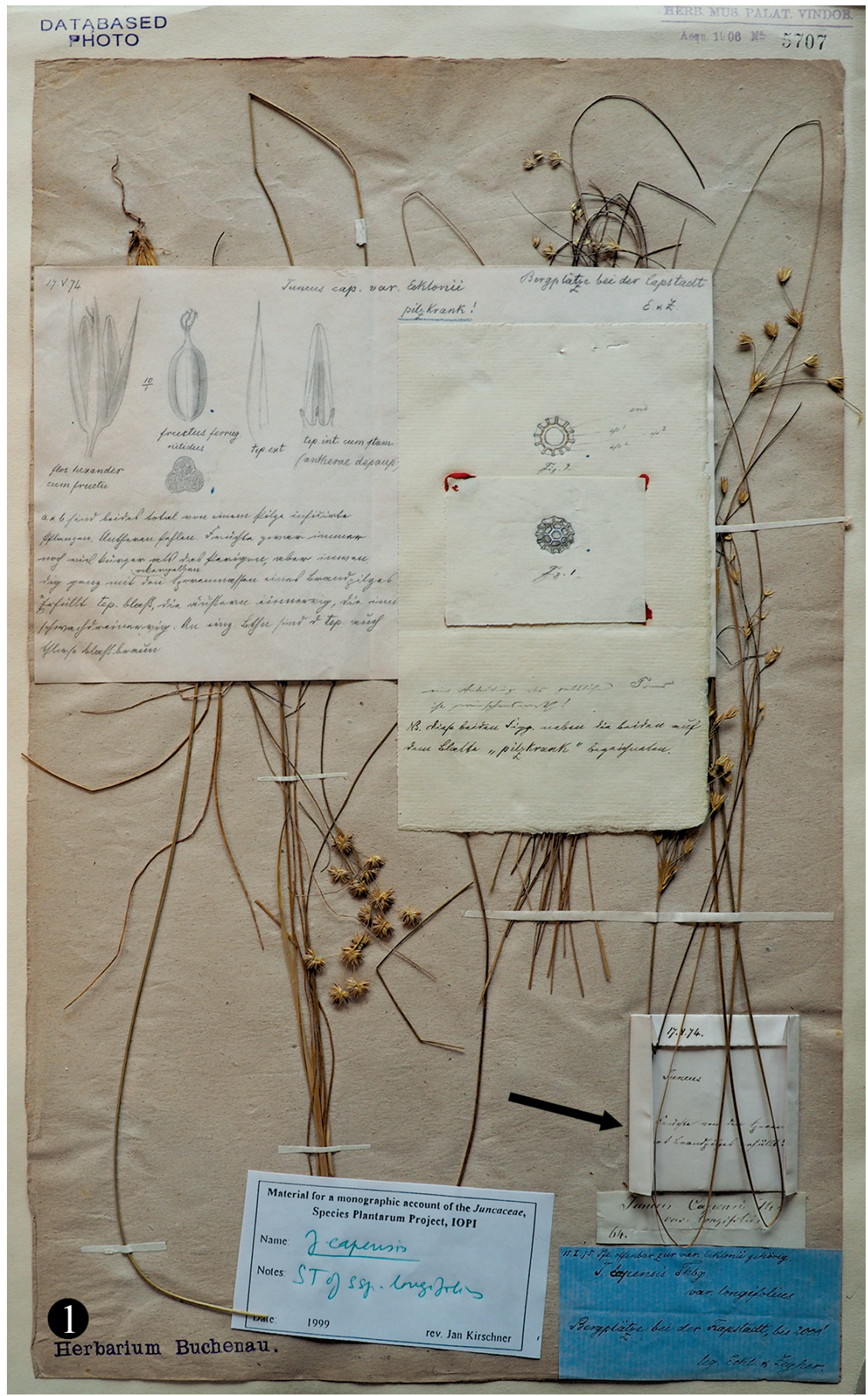

Fig. 1. Banerago capensis on Juncus capensis (W 1906-0005707). Black arrow shows the lectotype - a small packet, annotated '64, Juncus capensis var. longifolius'. 


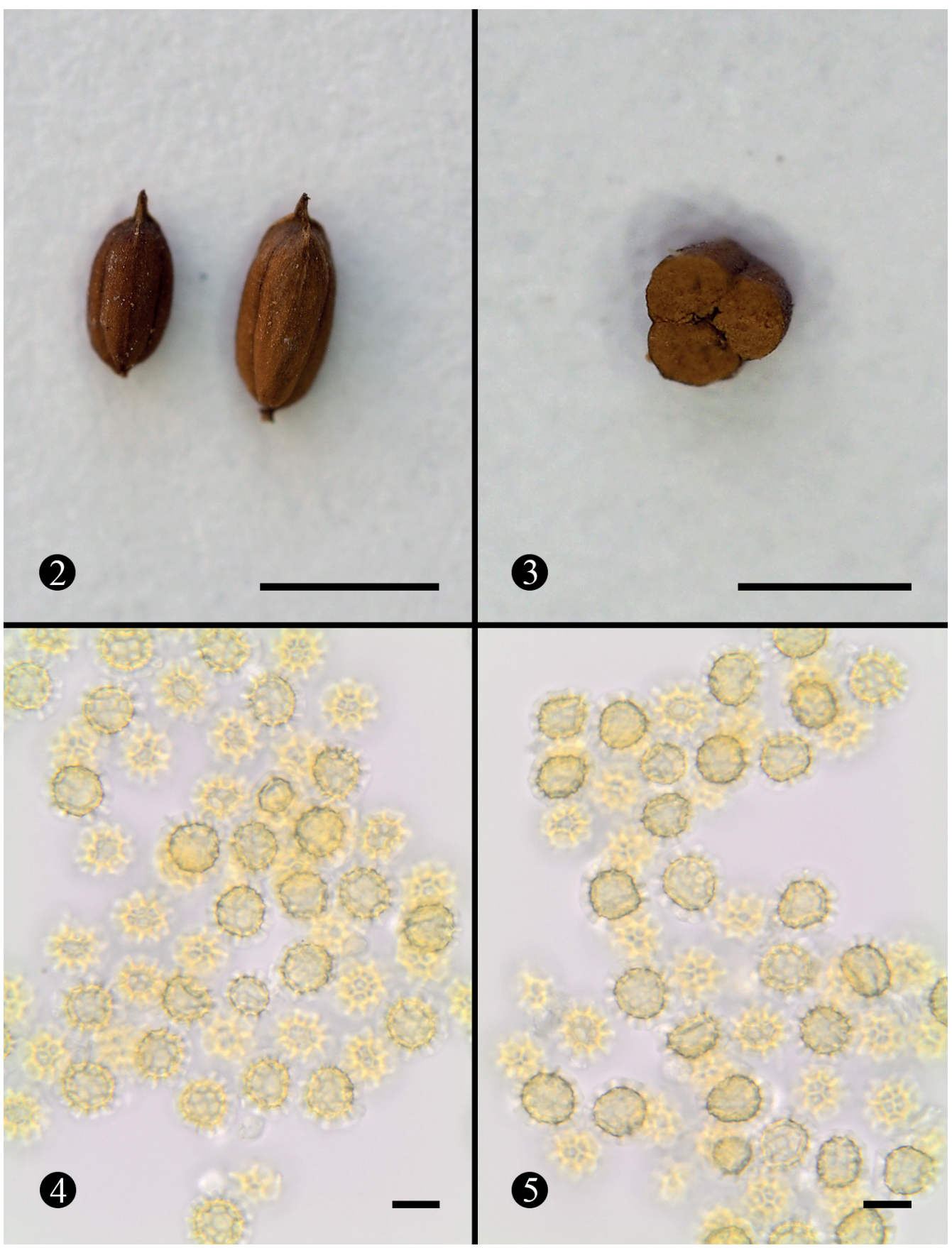

Figs 2-5. Bauerago capensis on Juncus capensis (W 1906-0005707). 2. Infected capsules, scale bar $=2 \mathrm{~mm}$. 3. Transversal section through an infected 3-locular capsule filled with a spore mass, scale bar $=1 \mathrm{~mm} .4,5$. Spores in LM, scale bars $=10 \mu \mathrm{m}$ 

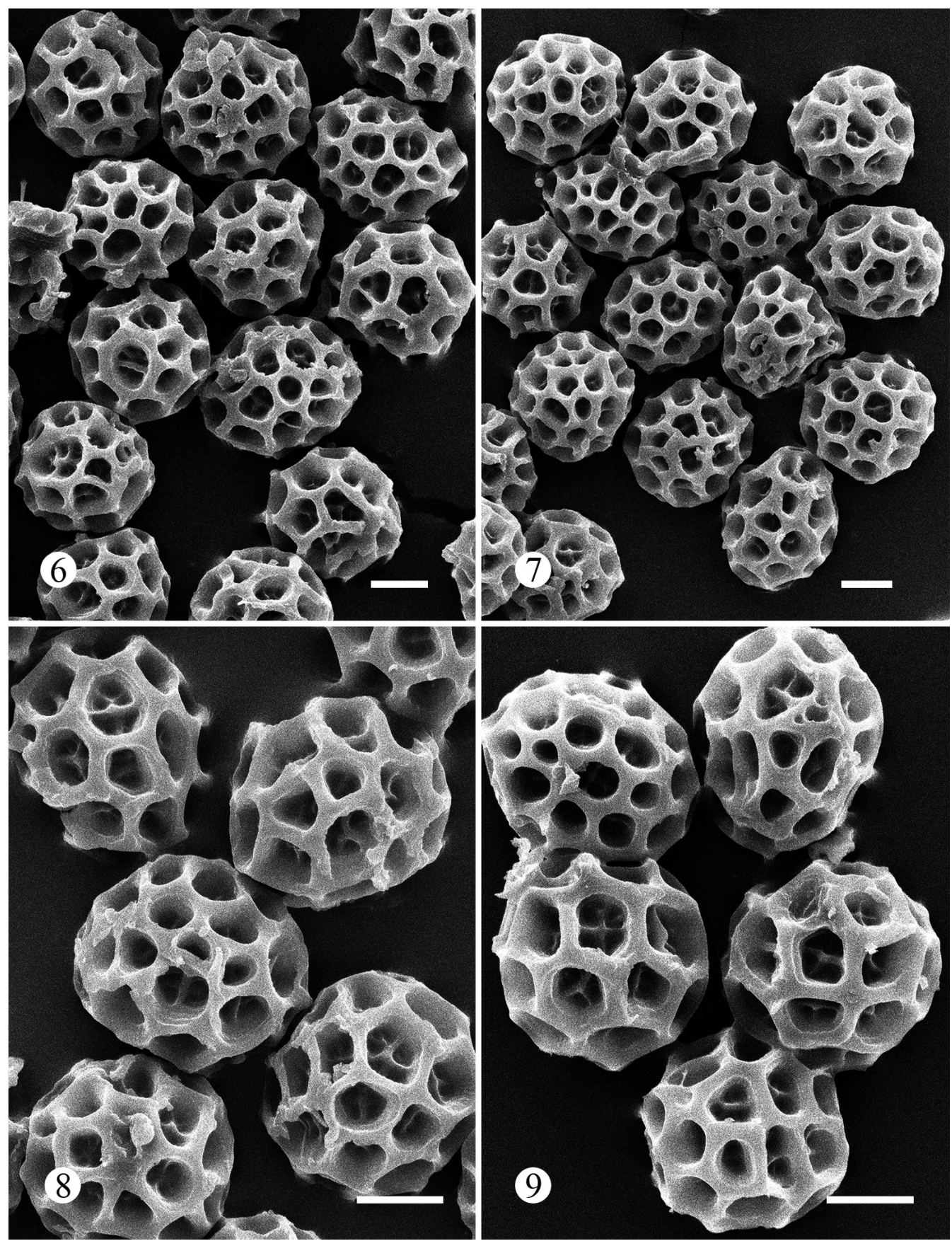

Figs 6-9. Bauerago capensis on Juncus capensis (W 1906-0005707) - spores in SEM, scale bars $=5 \mu \mathrm{m}$ 
brown, completely reticulate; spore wall (2.2-)2.5-3.7(-4.2) $\mu \mathrm{m}$ thick (including reticulum); meshes (2-)3-4(-5) per spore diameter, irregularly polyhedral, sometimes rounded, (1.0-)1.3-3.8(-4.5) $\mu \mathrm{m}$ long; muri (9-)10-13(-14) on equatorial circumference, in optical median view subacute, (1.1-) 1.3-2.6(-3.0) $\mu \mathrm{m}$ high; the interspaces often with lower muri, forming smaller meshes. In SEM spore wall bi-reticulate, one reticulum with irregularly polyhedral or irregularly rounded meshes, with a second reticulum in the interspaces with lower muri and smaller meshes.

Hosts and specimens - On Juncus capensis Thunb.: SOUTH AFRICA, WESTERN CAPE, mountains near Cape Town, ca 600 m (2000 ft.), December 1827, leg. C.F. Ecklon \& C.L.P. Zeyher (W 1906-0005707(!), lectotype, designated here - a small packet dated '17.V.74', annotated 'Standort 64, Juncus capensis var. longifolius', attached to a syntype sheet of J. capensis subsp. longifolius Buchenau) (Fig. 1). - On Juncus lomatophyllus Spreng., SOUTH AFRICA, WESTERN CAPE, Kirstenbosch at Table Mountain, near Cape Town, 18 Feb 1816, leg. K.H. Bergius (syntype, n.v.).

Distribution - On Juncaceae: Juncus sect. Graminifolii: Juncus capensis and J. lomatophyllus; Africa (South Africa).

It is difficult to determine the exact date when the specimen selected herein as a lectotype was collected. The annotation '17.V.74' (Fig. 1) refers to the date when the plant was studied by F. Buchenau. Based on Buchenau's comments about the infected specimen (Buchenau 1875: 486), it may be a duplicate of an Ecklon's specimen (no. 899), collected near Seekuhvalley, in December, 1827.

Juncus capensis is endemic to South Africa (Northern Cape, Western Cape, and Eastern Cape), while J. lomatophyllus is distributed in Zimbabwe, southern Mozambique, South Africa (Limpopo, Gauteng, Mpumalanga, KwaZulu-Natal, Western Cape, Eastern Cape), Swaziland, and Lesotho (Foden \& Potter 2005; Cholo \& Foden 2006). Juncus capensis subsp. longifolius Buchenau, cited as a host plant in Vánky (2011), is currently recognized as a synonym of $J$. capensis (Kirschner et al. 2002).

Bauerago capensis is known only from the Cape Floristic Region (from mountainous areas near Cape Town) - one of the world's biodiversity hotspots. The flora of this region comprises about 9000 species, $69 \%$ of which are endemic (Goldblatt \& Manning 2000). $6-9)$.

The spores of Bauerago capensis possess characteristic, bi-reticulate ornamentation (Figs

Acknowledgements. This research received support (Grant no. AT-TAF-6702) from the SYNTHESYS Project http://www.synthesys.info/ which is financed by European Community Research Infrastructure Action under the FP7 "Capacities" Program. The assistance of Dr Ernst Vitek and Dr Bruno Wallnöfer (Natural History Museum Vienna) is kindly acknowledged. The authors would also like to acknowledge Dr Roger G. Shivas (University of Southern Queensland, Toowoomba, Australia) and Dr Paul M. Kirk (Royal Botanic Gardens, Kew) for providing helpful comments on the manuscript. 


\section{References}

Buchenau, F. 1875. Monographie der Juncaceen vom Cap. - Abhandlungen Herausgegeben vom Naturwissenschaftlichen Verein zu Bremen 4: 393-512 + Pls III-XI.

Buchenau, F. 1906. Juncaceae. - In: A. Engler (ed.). Das Pflanzenreich (Regni Vegetabilis Conspectus). Heft 25(IV.36). Pp. 1-284. Verlag von Wilhelm Engelmann, Leipzig.

Cholo, F. \& Foden, W. 2006. Juncus lomatophyllus Spreng. National Assessment: Red List of South African Plants version 2017.1. Available from: http://redlist.sanbi.org/species.php?species=3634-31 (accessed 8 December 2017).

Foden, W. \& Potter, L. 2005. Juncus capensis Thunb. National Assessment: Red List of South African Plants version 2017.1. Available from: http://redlist.sanbi.org/species.php?species=3634-9 (accessed 8 December 2017).

Goldblatt, P. \& Manning, J. 2000. Cape plants: A conspectus of the Cape Flora of South Africa. - Strelitzia 9: $1-743$.

Kirschner, J. et al. 2002. Juncaceae 2: Juncus subg. Juncus. - In: A.E. Orchard (ed.). Species Plantarum: Flora of the World. Part 7. Pp. 1-336. Australian Biological Resources Study, Canberra, Australia.

Malençon, M.G. 1929. Ustilago abstrusa sp. nov. Ustilaginée nouvelle sur Juncus. - Bulletin de la Société Mycologique de France 45: 252-256.

Oudemans, C.A.J.A. \& Beijerinck, M. 1895. Ustilago Vuijckii. - Verslagen van de Zittingen der Wis- en Natuurkundige Afdeeling van de Koninklijke Akademie van Wetenschappen 3: (55)-(57).

Rayner, R.W. 1970. A mycological colour chart. Commonwealth Mycological Institute, Surrey \& British Mycological Society.

Reess, M. 1875a. Ustilago ? capensis n. sp., einen neuen Brandpilz vom Kap der guten Hoffnung. Sitzungsberichte der Physikalisch-Medizinischen Sozietät zu Erlangen 7: 70-72.

Reess, M. 1875b. Sitzungsbericht der physikalisch-medicinischen Societät zu Erlangen [Ustilago? capensis n. sp.]. - In: L. Rabenhorst (ed.). Repertorium. - Hedwigia 14: 109-112.

Reess, M. 1875c. Ustilago? capensis n. sp. - In: F. Buchenau. Monographie der Juncaceen vom Cap. Abhandlungen Herausgegeben vom Naturwissenschaftlichen Verein zu Bremen 4: 486-488 + Pl. XI (Figs 3, 4).

Saccardo, P.A. 1888. Ustilagineae Tul. (by J.B. de Tony). - In: Sylloge fungorum, etc. 7: 449-527.

Vánky, K. 2011['2012']. Smut fungi of the world. APS Press, St. Paul, Minnesota, USA.

Vánky, K. 2013. Illustrated genera of smut fungi. $3^{\text {rd }}$ edn. American Phytopathological Society Press, St. Paul, Minnesota, USA.

Vánky, K. \& McKenzie, E.H.C. 2002. Smut fungi of New Zealand. Fungi of New Zealand. Vol. 2. Fungal Diversity Research Series, no. 8. Fungal Diversity Press, Hong Kong.

Vánky, K., Vánky, C. \& Denchev, C.M. 2011. Smut fungi in Africa - a checklist. - Mycologia Balcanica 8: $1-77$.

Zundel, G.L. 1938. The Ustilaginales of South Africa. - Bothalia 3: 283-330. https://doi.org/10.4102/ abc.v3i3.1755 